\title{
Komparasi Pengaruh Tingkat Kesehatan Bank Terhadap Profitabilitas pada PT.Bank BCA,Tbk. dan PT.Bank BCA Syariah
}

\author{
Syukron Sazly \\ Universitas Bina Sarana Informatika \\ syukron.szy@bsi.ac.id \\ FeraNelfianti \\ Universitas Bina Sarana Informatika \\ fera.fnf@bsi.ac.id \\ Herudini Subariyanti \\ Universitas Bina Sarana Informatika \\ herudini.hdi@bsi.ac.id
}

\begin{tabular}{|c|c|}
\hline ak & $\begin{array}{l}\text { Tingkat Kesehatan Bank adalah salah satu alat ukur untuk menilai bank } \\
\text { mana yang beroperasi dengan baik dan mendapatkan kepercayaan dalam } \\
\text { melakukan transaksi perbankan. Penilaian tingkat kesehatan bank saat } \\
\text { ini menggunakan metode Risk Based-Bank Rating (RBBR) atau RGEC } \\
\text { menggantikan metode CAMELS, dengan Peringkat Komposit sebagai } \\
\text { tolak ukurnya. Penelitian ini bertujuan untuk melakukan komparasi } \\
\text { tingkat kesehatan dan pengaruhnya terhadap profitabilitas pada PT. } \\
\text { Bank BCA, Tbk dan PT. Bank BCA Syariah per-triwulan 2016-2020 } \\
\text { berdasarkan metode RBBR tersebut. Jenis penelitian ini adalah } \\
\text { deskriptif kuantitatif, dengan purposive sampling sebagai tehnik } \\
\text { pengambilan sampelnya. Sampel yang digunakan adalah kinerja } \\
\text { keuangan per-triwulan tahun 2016-2020 sebanyak 20 sampel. } \\
\text { Pengolahan data menggunakan SPSS 25. Profitabilitas diwakili oleh } \\
\text { Return On Assets (ROA) sebagai variabel dependen (Y) dan variabel } \\
\text { independennya adalah Capital Adequency Ratio (X1), Non Performing } \\
\text { Loans/Financing (X2), Net Interest/Operating Margin (X3), Biaya } \\
\text { Operasional/Pendapatan Operasional (X4) dan Rasio } \\
\text { Pinjaman/Pembiayaan terhadap Simpanan (X5). Hasilnya, pada PT. } \\
\text { Bank BCA, Tbk, semua variabel berada pada Peringkat Komposit-1 } \\
\text { (PK-1) yang berarti Sangat Sehat. Untuk PT. Bank BCA Syariah, hanya } \\
\text { komponen CAR, NPF, dan BOPO pada Peringkat Komposit-1 (PK-1), } \\
\text { tetapi untuk NOM pada Peringkat Komposit-4 (PK-4/Kurang Sehat), } \\
\text { FDR dan ROA Peringkat Komposit-3(PK-3/ Cukup Sehat). Secara } \\
\text { parsial terdapat perbedaan yang signifikan pada kedua bank tersebut } \\
\text { terkait variabel yang mempengaruhi profitabilitasnya yaitu BOPO pada } \\
\text { PT.Bank BCA, Tbk dan NOM pada PT.Bank BCA Syariah, Secara } \\
\text { simultan tidak terdapat perbedaan, dimana semua variabel tingkat secara } \\
\text { bersama-sama berpengaruh signifikan terhadap profitabilitasnya,myaitu } \\
\text { 78,2\% pada PT Bank BCA,Tbk dan 90,7\% pada PT BCA Syariah }\end{array}$ \\
\hline & \\
\hline
\end{tabular}




\section{PENDAHULUAN}

Tingkat kesehatan bank adalah salah satu alat ukur untuk menilai mana bank yang beroperasi dengan baik dan akan bertahan dan bahkan berkembang ditengah situasi perekonomian yang ada.. Menurut UU No.10 Tahun 1998 yang membagi bank menjadi Bank Umum dan BPR, maka dapat dikatakan bahwa bank konvensional dan bank syariah masuk dalam kategori bank umum yang dinilai dengan alat ukur yang sama, meskipun terdapat beberapa istilah yang berbeda. Terkait dengan hal tersebut, Bank Indonesia menerbitkan Peraturan Bank Indonesia Nomor 13/1/PBI/2011 pada tanggal 5 Januari 2011 mengenai kebijakan tingkat kesehatan bank umum yang tadinya ditentukan berdasarkan CAMELS menjadi RGEC yang lebih fokus pada manajemen resiko yang terdiri dari Risk Profile, Good Corporate Governance (GCG), Earning, dan Capital, yang sering juga disebut sebagai Risk Based Bank Rating (RBBR).

Tingkat kesehatan bank adalah kemampuan suatu bank untuk melakukan kegiatan operasional perbankan secara normal dan mampu memenuhi semua kewajibannya dengan baik dengan cara-cara yang sesuai dengan peraturan perbankan yang berlaku (Suhartono, 2017). Sementara (Rasyid , 2021) berpendapat, penerapan manajemen risiko dan prediksi risiko dapat membantu perusahaan menghemat pengeluaran sekaligus melindungi masa depan. (Pambudi, S., Darmawan, 2018) mengatakan penilaian bank dengan metode yang baru terlihat bahwa tingkat kesehatan bank, pengelolaan bank dan operasi yang dijalankan oleh bank merupakan tanggung jawab bank sepenuhnya. Pentingnya tingkat kesehatan bank, baik bank umum konvensional maupun bank umum syariah membuat peneliti tertarik untuk meneliti lebih lanjut khususnya pada PT.bank BCA,Tbk dan PT. bank BCA Syariah. Dalam penelitian ini, variabel tingkat kesehatan bank yang digunakan adalah rasio Non Performing Loan (NPL)/Non Performing Financing (NPF), Loan To Depoit Ratio (LDR)/ Financing to Deposit Ratio (FDR), Biaya Operasi/Pendapatan Operasi(BOPO), Net Interest Margin (NIM)/Net Operating Margin (NOM) dan Return On Asset (ROA) dan faktor permodalan (Capital) dapat dinilai dengan Capital Adequency Ratio (CAR((OJK), 2021)), Untuk variabel GCG/ Manajemen tidak digunakan karena sulit diperoleh oleh pihak eksternal. Dalam kasus tertentu GCG tidak menunjukkan pengaruh yang signifikan dan positif pada ROA artinya tinggi rendahnya GCG bank umum syariah di Indonesia, hal tersebut tidak berdampak pada keuntungan yang diperoleh bank(Rahman, 2020). Begitu juga dengan Islamic Corporate Governance (ICG) dan Zakat Performing Ratio (ZPR) untuk bank syariah, meski berpengaruh signifikan terhadap Kinerja Keuangan Bank Umum Syariah (Umiyati, 2020), namun tidak digunakan dalam pula dalam penelitian ini.

Beberapa penelitian terkait hal tersebut juga dilakukan oleh beberapa peneliti, diantaranya adalah Saputri Ramadhanti tentang analsisi perbandingan kinerja keuangan antara BCA dengan BCA Syariah berdasarkan rasio keuangan periode 2013-2019. Penelitian ini bertujuan untuk melihat perbandingan kinerja keuangan antara BCA yang menggunakan alat analisis perbandingan rasio keuangan yang terdiri dari CAR, ROA, LDR dan BOPO dalam periode tahun 2013 - 2019. Hasil dari rasio CAR menunjukkan bahwa BCA Syariah lebih tinggi dibandingkan dengan BCA. Untuk ROA BCA lebih tinggi dibandingkan dengan BCA Syariah, untuk LDR, BCA lebih tinggi dibandingkan BCA, sementara rasio BOPO menunjukkan bahwa BCA Syariah lebih tinggi dibandingkan dengan BCA yang menandakan bahwa biaya operasional pada BCA Syariah dalam kondisi bermasalah (Saputri Ramadhanti, 2021)

Penelitian kedua dilakukan oleh Diana Putri bertujuan untuk dapat melihat perbandingan tingkat kinerja keuangan BCA Konvensional dan BCA Syariah periode 
2016-2020 dengan menggunkan metode RGEC (Risk Profile, Good Corporate Governance, Earnings, dan Capital). Hasilnya , tingkat kesehatan BCA Konvensional dan BCA Syariah berbeda yang cukup signifikan pada variabel FDR/LDR, ROA, dan ROE sedangkan pada variabel (NPF/NPL), GCG dan CAR tidak berbeda secara signifikan. (Diana Putri, 2021)

Penelitian selanjutnya dilakukan oleh Dinar Riftiasari tentang perbandingan antara kinerja keuangan bank BCA konvensional dan bank BCA syariah dengan metode RGEC selama pandemi Covid-19. Penelitian ini menggunakan data sekunder berupa laporan keuangan triwulanan yang diterbitkan oleh bank BCA konvensional dan bank BCA syariah periodeMaret dan Juni 2020. Hasil penelitian menunjukkan terdapat perbedaan yang signifikan pada variabel CAR, ROA, LDR, NPL, dan BOPO tidak terdapat perbedaan yang signifikan selama pandemi Covid-19 (Dinar Riftiasari, 2020).

Sementara penelitian ini bertujuan untuk membandingkan tingkat kesehatan PT. Bank BCA,Tbk dan PT. Bank BCA Syariah dan pengaruhnya terhadap profitabilitas. Disini akan terlihat tingkat kesehatan dua bank dalam BCA Group dimana PT. Bank BCA Tbk. Bank dengan aset terbesar dan PT. Bank BCA Syariah yang relatif baru. Semestinya pengalaman membangun Bank BCA dapat membawa Bank BCA Syariah menjadi bank syariah terbesar pula. Peneliti menggunakan data yang bersifat kuantitatif berbasis RBBR berdasarkan peraturan OJK Nomor 8/POJK.03/2014, surat edaran OJK Nomor 10/SEOJK.03/2014 dan kodifikasi Bank Indonesia tahun 2012 (Bank Indonesia, 2012). Penelitian ini melengkapi penelitian terdahulu. Pada penelitian sebelumnya (Saputri Ramadhanti, 2021), peneliti hanya menggunakan empat variabel dan data bemum menggunakan data yang terbaru ,sementara penelitian (Diana Putri, 2021) telah menggunakan enam varibel dan data terbaru, namun hanya bersifat deskriptif tanpa pengujian statistik, sementara penelitian (Dinar Riftiasari, 2020) memiliki data yang sangat minim.

\section{LANDASAN TEORI}

Menurut (Kasmir, 2018), penilaian kesehatan bank perlu dilakukan baik bank umum konvensional maupun bank umum syariah. Hal tersebut perlu dan wajib dilakukan agar dapat memberi gambaran yang lebih tepat mengenai kondisi saat ini dan mendatang. Menurut (Andriyani Ima \& Mayasari, 2018) dua rasio yang berbeda dengan metode risiko CAMELS, yaitu profil dan tata kelola perusahaan yang baik menjadikan bank membutuhkan self assessment agar penilaian tersebut memiliki nilai komposit yang tinggi pada proses yang ada.

Peraturan Bank Indonesia Nomor 13/1/PBI/2011 pada tanggal 5 Januari 2011 yang fokus pada manajemen resiko yang terdiri dari Risk Profile, Good Corporate Governance (GCG), Earning, dan Capital, yang sering juga disebut sebagai Risk Based Bank Rating (RBBR) menghasilkan kriteria peringkat komposit seperti tabel1. di bawah ini:

Tabel 1.Kriteria Peringkat Komposit

Sumber : Kodifikasi PBI (2012)

Kriteria Peringkat Komposit ((OJK, 2016) : 
1. Peringkat Komposit 1 (PK-1), artinya kondisi bank secara umum sangat sehat, sehingga dinilai sangat mampu menghadapi pengaruh yang signifikan dari perubahan kondisi bisnis dan faktor eksternal lainnya.

2. Peringkat Komposit 2 (PK-2), PK-2 artinya kondisi bank secara umum sehat, sehingga dinilai mampu menghadapi pengaruh negatif yang signifikan dari perubahan kondisi bisnis dan faktor eksternal lainnya.

3. Peringkat Komposit 3 (PK-3), PK-3 artinya kondisi bank secara umum cukup sehat,

\begin{tabular}{|c|c|c|c|c|c|c|c|}
\hline $\begin{array}{l}\mathrm{P} \\
\mathrm{K}\end{array}$ & Rasio & Rasio & Rasio & Rasio & Rasio & Rasio & $\begin{array}{l}\text { Katego } \\
\text { ri }\end{array}$ \\
\hline 1 & $\begin{array}{l}\mathrm{CAR} \geq \\
12 \%\end{array}$ & NPL $<2 \%$ & $\begin{array}{l}\text { NIM > } \\
3 \%\end{array}$ & $\begin{array}{l}94 \% \geq \\
\text { BOPO }\end{array}$ & $\begin{array}{l}50 \% \\
<\mathrm{LDR} \leq 75 \\
\%\end{array}$ & $\begin{array}{l}\mathrm{ROA}>1 \\
.5 \%\end{array}$ & $\begin{array}{c}\text { Sangat } \\
\text { Sehat }\end{array}$ \\
\hline 2 & $\begin{array}{l}9 \% \leq \\
\text { CAR } \\
<12 \%\end{array}$ & $\begin{array}{l}2 \% \leq \mathrm{NPL} \\
\leq 5 \%\end{array}$ & $\begin{array}{l}2 \%< \\
\mathrm{NIM} \leq \\
3 \%\end{array}$ & $\begin{array}{l}94 \%< \\
\text { BOPO } \leq \\
95 \%\end{array}$ & $\begin{array}{l}75 \% \\
<\mathrm{LDR} \\
\leq 85 \%\end{array}$ & $\begin{array}{l}1.25 \% \\
<\mathrm{ROA} \leq \\
1.5 \%\end{array}$ & Sehat \\
\hline 3 & $\begin{array}{l}8 \% \leq \\
\text { CAR } \\
<9 \%\end{array}$ & $\begin{array}{l}5 \% \leq \mathrm{NPL} \\
\leq 8 \%\end{array}$ & $\begin{array}{l}1.5 \%<\mathrm{N} \\
\mathrm{IM} \leq \\
2 \%\end{array}$ & $\begin{array}{l}95 \%< \\
\text { BOPO } \leq \\
96 \%\end{array}$ & $\begin{array}{l}85 \% \\
<\mathrm{LDR} \leq \\
100 \%\end{array}$ & $\begin{array}{l}0.5 \% \\
<\mathrm{ROA} \leq \\
1.25 \%\end{array}$ & $\begin{array}{l}\text { Cukup } \\
\text { Sehat }\end{array}$ \\
\hline 4 & $\begin{array}{l}6 \% \leq \\
\text { CAR } \\
<8 \%\end{array}$ & $\begin{array}{l}8 \% \leq \mathrm{NPL} \\
\leq 12 \%\end{array}$ & $\begin{array}{l}1 \%<\mathrm{NI} \\
\mathrm{M} \leq \\
1.5 \%\end{array}$ & $\begin{array}{l}96 \%< \\
\text { BOPO } \leq \\
97 \%\end{array}$ & $\begin{array}{l}100 \% \\
<\mathrm{LDR} \leq \\
120 \%\end{array}$ & $\begin{array}{l}0 \% \\
<\mathrm{ROA} \leq \\
0.5 \%\end{array}$ & $\begin{array}{c}\text { Kurang } \\
\text { Sehat }\end{array}$ \\
\hline 5 & $\begin{array}{l}\text { CAR } \leq \\
6 \%\end{array}$ & $\begin{array}{l}\text { NPL } \geq \\
12 \%\end{array}$ & $\begin{array}{l}\text { NIM } \\
\leq 1 \%\end{array}$ & $\begin{array}{l}\text { BOPO > } \\
97 \%\end{array}$ & $\begin{array}{l}100 \% \\
<\mathrm{LDR} \leq \\
120 \%\end{array}$ & $\begin{array}{l}\mathrm{ROA} \leq \\
0 \%\end{array}$ & $\begin{array}{l}\text { Tidak } \\
\text { Sehat }\end{array}$ \\
\hline
\end{tabular}

sehingga dinilai cukup mampu menghadapi pengaruh negatif yang signifikan dari perubahan kondisi bisnis dan faktor eksternal lainnya.

4. Peringkat Komposit 4 (PK-4), PK-4 artinya kondisi bank secara umum kurang sehat, sehingga dinilai kurang mampu menghadapi pengaruh negatif yang signifikan dari perubahan kondisi bisnis dan faktor eksternal lainnya.

5. Peringkat Komposit 5 (PK-5), PK-5 artinya kondisi bank secara umum tidak sehat, sehingga dinilai tidak mampu menghadapi pengaruh negatif yang signifikan dari perubahan kondisi bisnis dan faktor eksternal lainnya.

\section{METODOLOGI PENELITIAN}

Yang menjadi sampel dalam penelitian ini adalah kinerja keuangan PT. Bank BCA,Tbk. dan PT. Bank BCA Syariah per-triwulan dari tahun 2016 sampai 2020((OJK), 2021). Pertimbangan nya dengan 5 tahun data yang ada cukup mewakili kinerja keuangan yang terakhir. Dari data tersebut yang berdasarkan laporan keuangan bank konvensional dan bank syariah pada website Otoritas Jasa Keuang tahun 2021(OJK, 2021), maka diperoleh 20 sampel $(\mathrm{N}=20)$. Dalam penelitian ini indikator Profitabilitas PT. Bank BCA, Tbk diwakili oleh Return On Asset (ROA) sebagai variabel independen(Y) dan untuk variabel bebasnya adalah Capital Adequency Ratio(X1), Non Performing Loan (X2), Net InterestMargin(X3), Belanja Operasional dari Pendapatan Operasional(X4) dan Loan to Deposit Ratio(X5). Pada PT. Bank BCA Syariah, indikator Profitabilitasnya diwakili oleh Return On Asset (ROA) sebagai variable independen (Y) dan variabel bebasnya adalah Capital Adequency Ratio(X1), Non Performing Financing 
(X2), Net Operating Margin(X3), Belanja Operasional dari Pendapatan Operasional (X4) dan Financing to Deposit Ratio(X5).Perbedaan beberapa istilah diatas karena perbedaan sistim bank, tetapi prinsip perhitungan kinerja keuangan adalah sama.

Analisis data yang dilakukan oleh penelitian ini terhadap data tersebut adalah Uji asumsi klasik dimana dalam penelitian uji asumsi klasik yang digunakan adalah uji normalitas, uji multikolonieritas, uji heteroskedastisitas, uji autokorelasi (Zainuddin, 2016), Uji Regresi Linier Berganda untuk memprediksi bagaimana keadaan (naik turunnya variabel dependen, ketika dua atau lebih variabel independen sebagai faktor prediktor dimanipulasi (kenaikan dan penurunan nilai) (Rahadjeng, 2017), Uji Koefisien Determinan (R2) digunakan untuk mengetahui persentase hubungan antara independen dan dependen. Besarnya persentase pengaruh semua variabel terhadap nilai dependen dapat dilihat dari besarnya koefisien determinan (R2) persamaan regresi (Manik, 2017).

Uji $\mathrm{t}$ digunakan untuk menguji apakah masing-masing variabel independen secara individual berpengaruh signifikan terhadap variabel dependen Uji f digunakan untuk mengetahui pengaruh rasio CAR), (NPL atau NPF),NIM atau NOM), rasio BOPO dan rasio LDR atau FDR secara bersama-sama terhadap profitabilitas (ROA). (Danar Maharudin, 2019).

\section{HASIL PENELITIAN}

Beberapa ui asumsi klasik PT.Bank BCA,Tbk dan PT. Bank BCA Syariah dapat terlihat dalam gambar dan tabel berikut;

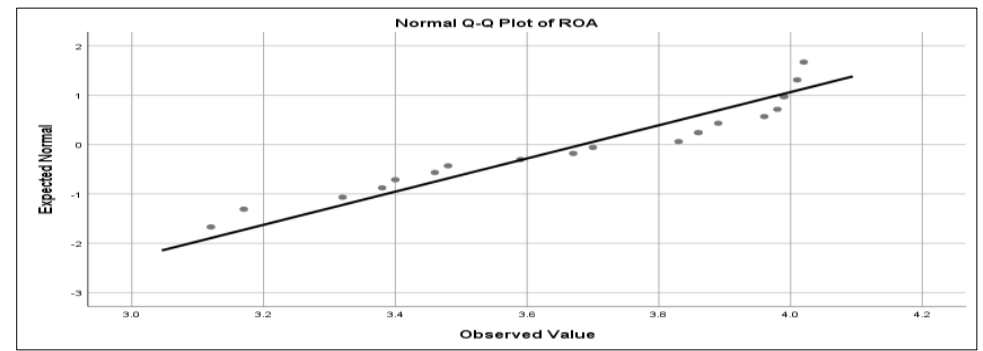

Gambar 1.Hasil Uji Normalitas PT. Bank BCA,Tbk Sumber gambar: Data Penelitian,2021

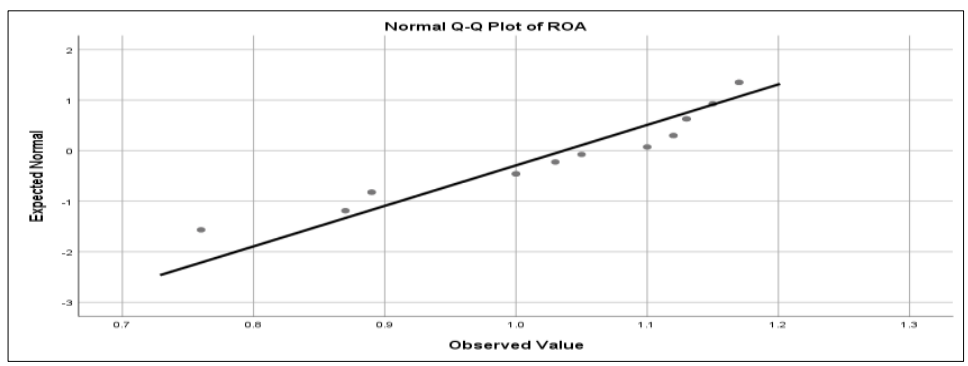

Gambar 2.Hasil Uji Normalitas PT. Bank BCA Syariah Sumber : Data Penelitian, 2021

Pada gambar 1 dan 2 terlihat titik-titik yang menggambarkan data mengikuti garis normal, sehigga model regresi PT.Bank BCA,Tbk dan PT.Bank BCA Syariah berdistribusi normal.

Tabel 1. Uji Multikolonieritas PT. Bank BCA,Tbk 


\begin{tabular}{|c|c|c|c|c|c|c|c|c|}
\hline \multirow[t]{2}{*}{ Model } & \multirow{2}{*}{$\begin{array}{c}\text { Stand.Coefficients } \\
\text { Beta }\end{array}$} & \multirow[t]{2}{*}{$t$} & \multirow[t]{2}{*}{ Sig. } & \multicolumn{3}{|c|}{ Correlations } & \multicolumn{2}{|c|}{$\begin{array}{l}\text { Collinearity } \\
\text { Statistics }\end{array}$} \\
\hline & & & & Z-order & Partal & Part & TIrnce & VIF \\
\hline (Con) & & 1.607 & .130 & & & & & \\
\hline CAR & .059 & .292 & .774 & -.299 & .078 & .031 & 286 & 3.499 \\
\hline NPL & -.097 & -.506 & .620 & -.636 & -.134 & -.054 & .312 & 3.209 \\
\hline NIM & .346 & 1.958 & .070 & .574 & .464 & .210 & .367 & 2.722 \\
\hline BOPO & -.644 & -4.751 & .000 & -.797 & .786 & -.509 & .625 & 1.601 \\
\hline LDR & .164 & 1.262 & .228 & .507 & .320 & .135 & .680 & 1.470 \\
\hline
\end{tabular}

Sumber : Data Penelitian, 2021

Berdasarkan Tabel.1, data untuk kondisi VIF adalah : CAR $(0.059,<10)$, NPL $(-0.097<$ $10.00)$, NIM $(0.346<10,00)$, BOPO $(-0.644<10,00)$ dan LDR $(0.164<10,00)$ dan untuk kondisi Tolerance adalah CAR $(0.286>0.1)$ NPL $(0,312>0,100)$, NIM $(0,367>0,100)$, BOPO $(0,625>0,100)$, dan LDR ( 0,680>0,100), maka kesimpulannya tidak terjadi gejala multikolonieritas pada data PT. Bank BCA,Tbk

Tabel 2. Uji Multikolonieritas PT.Bank BCA Syariah

\begin{tabular}{|c|c|c|c|c|c|c|c|c|}
\hline \multirow[t]{2}{*}{ Model } & \multirow{2}{*}{$\begin{array}{c}\begin{array}{c}\text { Standardized } \\
\text { Coefficients }\end{array} \\
\text { Beta }\end{array}$} & \multirow[t]{2}{*}{$t$} & \multirow[t]{2}{*}{ Sig. } & \multicolumn{3}{|c|}{ Correlations } & \multicolumn{2}{|c|}{$\begin{array}{l}\text { Collinearity } \\
\text { Statistics }\end{array}$} \\
\hline & & & & $\begin{array}{l}\text { Zero- } \\
\text { order }\end{array}$ & $\begin{array}{c}\text { Partia } \\
\mid\end{array}$ & Part & Tolerance & VIF \\
\hline (Const) & & -.521 & .614 & & & & & \\
\hline CAR & .043 & .420 & .684 & -.552 & .132 & .033 & .598 & 1.672 \\
\hline NPF & -.065 & -.766 & .462 & -.157 & -.235 & $\begin{array}{l}- \\
.060\end{array}$ & .855 & 1.169 \\
\hline NOM & 1.033 & $\begin{array}{l}7.86 \\
8\end{array}$ & .000 & .964 & .928 & .620 & .361 & 2.773 \\
\hline BOPO & .076 & .687 & .508 & -.620 & .212 & .054 & .514 & 1.945 \\
\hline FDR & -.004 & $\begin{array}{l}.036 \\
\end{array}$ & .972 & -.514 & -.011 & $\begin{array}{l}- \\
.003\end{array}$ & .588 & 1.700 \\
\hline
\end{tabular}

Sumber : Data Penelitian, 2021

Berdasarkan tabel 2. diatas data untuk kondisi VIF adalah : CAR $(0.043,<10)$, NPF ($0.065<10.00)$, NOM $(1,033<10,00)$, BOPO $(-0,076<10,00)$ dan FDR $(-0.04<10,00)$ dan untuk kondisi Tolerance adalah CAR $(0.598>0.1) \mathrm{NPF}(0,855>0,100)$, NOM $(0,361$ $>0,100)$, $\mathrm{BOPO}(0,514>0,100)$, dan FDR $(0,588>0,100)$, maka kesimpulannya tidak terjadi gejala multikolonieritas pada data PT. Bank BCA Syariah..

Hasil Uji Heteroskedastisitas pada PT.Bank BCA,Tbk dan PT. Bank BCA Syariah adalah pada gambar 3 dan gambar 4 berikut ; 


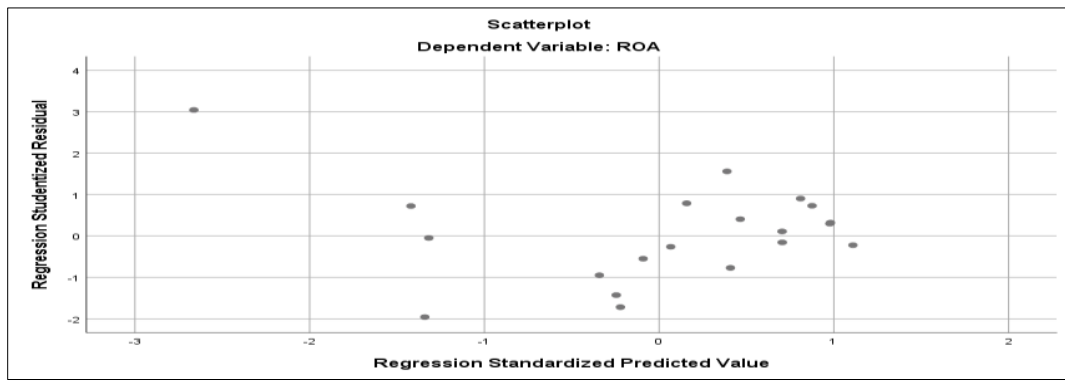

Gambar 3. Model Scatterplot PT.Bank BCA,Tbk

Sumber : Data Penelitian, 2021

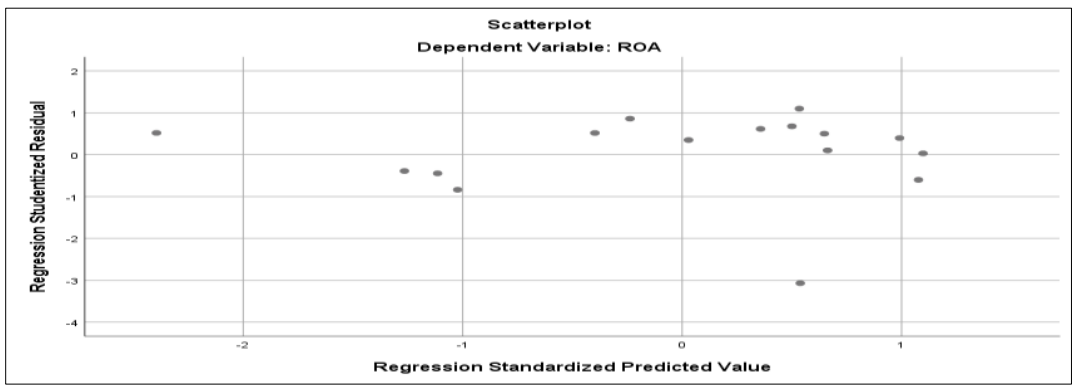

Gambar 4. Model Scatterplot PT.Bank BCA syariah Sumber: Data Penelitian, 2021

Untuk Uji autokorelasi, pada PT.BCA,Tbk, nilai Durbin-Watson $1.992>1908$ (batas atas ) dan kurang dari (k-batas atas )( 3.062 pada $\mathrm{k}=5, \quad \mathrm{~N}=20$ maka tidak terjadi autokorelasi. Untuk BCA Syariah, nilai Durbin-Watson $2.124>1908$, juga tidak terjadi autokorelasi.

Tabel 3. Uji Regresi Linier Berganda PT.Bank BCA,Tbk

\begin{tabular}{|c|c|c|c|c|c|c|}
\hline \multicolumn{7}{|c|}{ Coefficients $^{\mathrm{a}}$} \\
\hline \multirow{2}{*}{\multicolumn{2}{|c|}{ Model }} & \multicolumn{2}{|c|}{$\begin{array}{l}\text { Unstandardized } \\
\text { Coefficients }\end{array}$} & \multirow{2}{*}{$\begin{array}{c}\text { Standardized } \\
\text { Coefficients } \\
\text { Beta }\end{array}$} & \multirow[t]{2}{*}{$t$} & \multirow[t]{2}{*}{ Sig. } \\
\hline & & $B$ & Std. Error & & & \\
\hline \multirow[t]{6}{*}{1} & (Constant) & 3.501 & 2.178 & & 1.607 & .130 \\
\hline & CAR & .015 & .050 & .059 & .292 & .774 \\
\hline & NPL & -.231 & .457 & -.097 & -.506 & .620 \\
\hline & NIM & .306 & .156 & .346 & 1.958 & .070 \\
\hline & BOPO & -.046 & .010 & -.644 & -4.751 & .000 \\
\hline & LDR & .012 & .010 & .164 & 1.262 & .228 \\
\hline
\end{tabular}

Sumber : Data Penelitian, 2021

Dari data pada tabel 3. diperoleh persamaan garis regresi :

$$
\begin{gathered}
\mathrm{Y}=3,501+\{(0.15) \mathrm{X} 1+(-0.231) \mathrm{X} 2+(0.306 \mathrm{X} 3+(-0.046) \mathrm{X} 4+0.12 \mathrm{X} 5\} \\
\text { atau } \\
\mathrm{ROA}=3,501+0.15 \mathrm{CAR}-0.231 \mathrm{NPL}+0.306 \mathrm{NIM}-0.046 \mathrm{BOPO}+0.12 \mathrm{LDR}
\end{gathered}
$$


Tabel 4. Uji Regresi Linier Berganda PT.Bank BCA Syariah

\begin{tabular}{|c|c|c|c|c|c|c|}
\hline \multicolumn{7}{|c|}{ Coefficients $^{a}$} \\
\hline \multirow{2}{*}{\multicolumn{2}{|c|}{ Model }} & \multicolumn{2}{|c|}{ Unstandardized Coefficients } & \multirow{2}{*}{$\begin{array}{c}\text { Standardized Coefficients } \\
\text { Beta }\end{array}$} & \multirow[t]{2}{*}{$\mathrm{t}$} & \multirow[t]{2}{*}{ Sig. } \\
\hline & & B & Std. Error & & & \\
\hline \multirow[t]{6}{*}{1} & (Constant) & -.462 & .887 & & -.521 & .614 \\
\hline & CAR & .001 & .002 & .043 & .420 & .684 \\
\hline & NPF & -.051 & .066 & -.065 & -.766 & .462 \\
\hline & NOM & .986 & .125 & 1.033 & 7.868 & .000 \\
\hline & BOPO & -.005 & .007 & .076 & .687 & .508 \\
\hline & FDR & .001 & .007 & -.004 & -.036 & .972 \\
\hline
\end{tabular}

Sumber: Data Penelitian, 2021

Dari data pada tabel 4. diperoleh persamaan garis regresi :

$$
\begin{gathered}
\mathrm{Y}=-0.462+\{(0.01) \mathrm{X} 1+(-0.051) \mathrm{X} 2+(0.986) \mathrm{X} 3+(0.005) \mathrm{X} 4+0.00 \mathrm{X} 5\} \\
\text { atau } \\
\mathrm{ROA}=-0.462+0.01 \mathrm{CAR}-0.051 \mathrm{NPF}+0.986 \mathrm{NOM}-0.005 \mathrm{BOPO}+0.01 \mathrm{FDR}
\end{gathered}
$$

\section{Pengujian Hipotesis}

Uji Koefisien Determinan (R2)

Dari tabel di atas, pada PT.Bank BCA,Tbk, koefisien determinan (R2) menunjukkan angka Adjusted R Square sebesar 0,782 atau 78.2\% artinya variasi tingkat profitabilitas dapat dijelaskan oleh variabel CAR, NPL, NIM, BOPO dan LDR, sisanya $21.8 \%$ dapat dijelaskan oleh faktor lain.Untuk PT.Bank BCA Syariah, angka Adjusted R Square nya 0,907 atau $90.7 \%$ artinya variasi tingkat profitabilitas dapat dijelaskan oleh variabel CAR, NPF, NOM, BOPO dan FDR, sisanya sebesar $19.3 \%$ dapat dijelaskan oleh faktor lain.

\section{a. $\quad$ Uji Parsial (Uji t)}

Uji $\mathrm{t}$ digunakan untuk menguji apakah masing-masing variabel independen secara individual memiliki pengaruh yang signifikan terhadap variabel dependen pada tingkat

\begin{tabular}{|c|c|c|c|c|c|c|}
\hline \multicolumn{7}{|c|}{ Coefficients $^{a}$} \\
\hline \multirow{2}{*}{\multicolumn{2}{|c|}{ Model }} & \multicolumn{2}{|c|}{$\begin{array}{l}\text { Unstandardized } \\
\text { Coefficients }\end{array}$} & \multirow{2}{*}{$\begin{array}{c}\text { Standardized Coefficients } \\
\text { Beta }\end{array}$} & \multirow[t]{2}{*}{$t$} & \multirow[t]{2}{*}{ Sig. } \\
\hline & & $B$ & Std. Error & & & \\
\hline \multirow[t]{6}{*}{1} & (Cont) & 3.501 & 2.178 & & 1.607 & .130 \\
\hline & CAR & .015 & .050 & .059 & .292 & .774 \\
\hline & NPL & -.231 & .457 & -.097 & -.506 & .620 \\
\hline & NIM & .306 & .156 & .346 & 1.958 & .070 \\
\hline & BOPO & -.046 & .010 & -.644 & -4.751 & .000 \\
\hline & LDR & .012 & .010 & .164 & 1.262 & .228 \\
\hline
\end{tabular}
signifikan 0,05, dengan hasil uji pada tabel 6 sebagai berikut;

Tabel 6. Uji t PT.Bank BCA,Tbk

\section{Sumber : Data Penelitian,2021}

Pada Tabel 6 , hasil uji parsial dapat dilihat dari koefisien output SPSS, jika t hitung $>\mathrm{t}$ tabel, artinya variabel bebas (x) secara parsial berpengaruh terhadap variabel terikat (Y). Dari penelitian ini nilai $\mathrm{t}$ tabel $=(\dot{\alpha} / 2 ; \mathrm{n}-\mathrm{k}-1)=(0,05 / 2 ; 20-5-1)=(0,025 ; 14)=2.1448$. 
Pada PT.Bank BCA,Tbk, berdasarkan hasil uji t untuk variabel CAR diperoleh t- hitung (0.292) < t-tabel (2.1448), maka H0 diterima dan H1 ditolak. Berarti CAR (X1) secara parsial tidak berpengaruh signifikan terhadap ROA(Y). Begitu juga NPL (X2) diperoleh t- hitung $(-0.506)<\mathrm{t}$-tabel (2.1448), NIM (X3) diperoleh t- hitung (1.958) < t-tabel (2.1448) , dan LDR(X4) diperoleh t- hitung (1.262) < t-tabel (2.1448), yang berarti masing-masing variabel secara parsial tidak berpengaruh signifikan terhadap ROA(Y). Tetapi untuk BOPO (X4) diperoleh t- hitung $(-4.751)<\mathrm{t}$-tabel $(-2.1448)$ yang artinya BOPO (X4) berpengaruh negatif signifikan terhadap ROA(Y).

Tabel 7. Uji t PT.Bank BCA Syariah

\begin{tabular}{|c|c|c|c|c|c|c|}
\hline \multicolumn{7}{|c|}{ Coefficients $^{a}$} \\
\hline \multirow{2}{*}{\multicolumn{2}{|c|}{ Model }} & \multicolumn{2}{|c|}{$\begin{array}{l}\text { Unstandardized } \\
\text { Coefficients }\end{array}$} & \multirow{2}{*}{$\begin{array}{c}\text { Standardized } \\
\text { Coefficients } \\
\text { Beta }\end{array}$} & \multirow[t]{2}{*}{$\mathrm{t}$} & \multirow[t]{2}{*}{ Sig. } \\
\hline & & B & Std.-Error & & & \\
\hline \multirow[t]{6}{*}{1} & (Constant) & -.462 & .887 & & -.521 & .614 \\
\hline & CAR & .001 & .002 & .043 & .420 & .684 \\
\hline & NPF & -.051 & .066 & -.065 & -.766 & .462 \\
\hline & $\mathrm{NOM}$ & .986 & .125 & 1.033 & 7.868 & .000 \\
\hline & BOPO & .005 & .007 & .076 & .687 & .508 \\
\hline & FDR & .000 & .007 & -.004 & -.036 & .972 \\
\hline
\end{tabular}

Sumber : Data Penelitian, 2021

Pada Tabel 7, untuk PT.Bank BCA Syariah, berdasarkan hasil uji t untuk variabel CAR (X1) diperoleh t- hitung (-0.420) < t-tabel (2.1448), maka H0 diterima dan H1 ditolak. Berarti CAR (X1) secara parsial tidak berpengaruh signifikan terhadap ROA(Y). Begitu juga NPF (X2) diperoleh t- hitung (-0.766) < t-tabel (2.1448), BOPO (X4) diperoleh thitung $(0.687<\mathrm{t}$-tabel $(2.1448)$ dan FDR(X5) diperoleh $\mathrm{t}$ - hitung $(1.262)<\mathrm{t}$-tabel (2.1448) yang berarti masing-masing secara parsial tidak berpengaruh signifikan terhadap ROA(Y). Teapi Untuk NOM (X3) diperoleh t- hitung (7.868) > t-tabel (2.1448), maka $\mathrm{H} 0$ ditolak dan $\mathrm{H} 1$ diterima. Berarti hanya NOM (X3) secara parsial berpengaruh positif signifikan terhadap ROA(Y)

Tabel 8. Uji F PT.Bank BCA,Tbk dan PT. Bank BCA Syariah

\begin{tabular}{|c|c|c|c|c|c|c|}
\hline \multicolumn{7}{|c|}{ ANOVA $^{a}$} \\
\hline \multicolumn{2}{|c|}{ PT.Bank BCA,Tbk } & Sum of & df & Mean Square & $\mathrm{F}$ & Sig. \\
\hline \multirow[t]{3}{*}{1} & Regression & 1.414 & 5 & .283 & 14.635 & $.000^{\mathrm{b}}$ \\
\hline & Residual & .271 & 14 & .019 & & \\
\hline & Total & 1.685 & 19 & & & \\
\hline \multicolumn{7}{|c|}{ a. Dependent Variable: ROA } \\
\hline \multicolumn{7}{|c|}{ b. Predictors: (Constant), LDR, BOPO, CAR, NIM, NPL } \\
\hline
\end{tabular}

\begin{tabular}{|c|c|c|c|c|c|c|}
\hline \multicolumn{7}{|c|}{ ANOVA $^{a}$} \\
\hline \multicolumn{2}{|c|}{ PT. Bank BCA Syariah } & Sum of & df & Mean Square & $\mathrm{F}$ & Sig. \\
\hline \multirow[t]{3}{*}{1} & Regression & .219 & 5 & .044 & 30.178 & $.000^{\mathrm{b}}$ \\
\hline & Residual & .015 & 10 & .001 & & \\
\hline & Total & .234 & 15 & & & \\
\hline \multicolumn{7}{|c|}{ a. Dependent Variable: ROA } \\
\hline \multicolumn{7}{|c|}{ b. Predictors: (Constant), FDR, NPF, CAR, BOPO, NOM } \\
\hline
\end{tabular}

Sumber : Data Penelitian, 2021 
Berdasarkan hasil uji F pada tabel 8 variabel tingkat kesehatan bank (CAR, NPL, NIM, BOPO, LDR) diperoleh t-hitung (14.635) > t-tabel (2.1448), maka H0 ditolak dan H1 diterima. Berarti kesehatan bank (CAR, NPL, NIM, LDR) secara simultan berpengaruh signifikan terhadap profitabilitas (ROA) PT.Bank BCA,Tbk. Untuk PT.Bank BCA Syariah.diperoleh t- hitung (30.178) > t-tabel (2.1448), maka H0 ditolak dan H1 diterima. Berarti tingkat kesehatan bank (CAR,NPF,NOM,BOPO,FDR) secara simultan berpengaruh signifikan terhadap profitabilitas (ROA).

Berdasarkan hasil olah data SPSS 25 yang ditunjukkan hasil statistik deskriptif, untuk komponen CAR berada pada angka 23,2\%, jauh di atas $12 \%$ yang berarti berada dalam kategori Sangat Sehat, NPL pada angka 0,49\%, di bawah $2 \%$ yang berarti Sangat Sehat. Sementara untuk NIM 6,3\%, jauh diatas 3\% yang berarti Sangat Sehat, BOPO pada angka $62.8 \%$ jauh dibawah 94\% yang berarti Sangat Sehat, LDR 76,8\% Sangat Sehat dan ROA pada angka $3.68 \%$, berada diatas $1.5 \%$ yang berarti Sangat Sehat. Berarti jika digunakan peringkat komposit, maka semua komponen yang menunjukkan tingkat kesehatan bank BCA berada pada Peringkat Komposit -1 (PK-1)

Sementara itu hasil statistik deskriptif pada tabel diperoleh rata-rata skor tingkat kesehatan PT.Bank BCA Syariah tahun 2016-2020, untuk komponen CAR berada pada angka 33,68\%, jauh di atas $12 \%$ yang berarti berada dalam kategori Sangat Sehat, NPF pada angka 0,27\%, dibawah 2\% yang berarti Sangat Sehat. Sementara untuk NOM 1,1\%, jauh dibawah 3\% yang berarti Kurang Sehat. Hal ini harus menjadi perhatian pengelola karena banyak penelitian yang menunjukkan CAR yang tinggi berkorelasi negatif dengan profitabilitasnya (Mukhlis, 2012), BOPO pada angka $89.38 \%$ masih dibawah 94\% yang berarti Sangat Sehat. Ini menjadi penting karena BOPO menunjukkan efisiensi, yang saat ini merupakan tantangan road map OJK terkait bank syariah di Indonesia(Hendrawan dkk, 2020). Untuk FDR 90.02\% Cukup Sehat dan ROA pada angka $1,04 \%$, berada dibawah $1.5 \%$ yang berarti Cukup Sehat. Dari data tersebut, maka hanya komponen CAR, NPF dan BOPO berada pada Peringkat Komposit-1 (PK-1), sementara untuk NOM pada Peringkat Komposit-4 (PK-4), FDR Peringkat Komposit-3 (PK-3) dan ROA Peringkat Komposit-3 (PK-3).

Pada uji pengaruh, untuk PT.Bank BCA,Tbk terlihat koefisien determinan (R2) menunjukkan angka Adjusted R Square sebesar 0,782 atau 78.2 \% yang berarti yang berarti variasi tingkat profitabilitas dapat dijelaskan oleh tingkat kesehatan bank dengan indikator CAR, NPL, NIM, BOPO dan LDR, sisanya sebesar $21.8 \%$ dapat dijelaskan oleh faktor lain. Sementara untuk PT. Bank BCA Syariah angka Adjusted R Square nya adalah sebesar 0,907 atau $90.7 \%$ yang berarti variasi tingkat profitabilitas dapat dijelaskan oleh tingkat kesehatan bank dengan indikator CAR, NPF, NOM, BOPO dan FDR, sisanya sebesar $19.3 \%$ dapat dijelaskan oleh faktor lain.

Untuk PT.Bank BCA,Tbk, secara parsial hanya variabel $\mathrm{BOPO}(\mathrm{X} 4)$ yang berpengaruh negatif signifikan terhadap tingkat profitabilitas (ROA), sementara untuk PT.Bank BCA Syariah hanya NOM (X3) yang secara parsial berpengaruh positif signifikan terhadap profitabilitas (ROA). Secara simultan, baik pada PT. Bank BCA,Tbk maupun pada PT.Bank BCA Syariah semua indikator kesehatan bank berpengaruh secara signifikan. Hasil ini berbeda dengan peneltian sebelumnya. (Diana Putri, 2021) dimana, tingkat kesehatan BCA Konvensional dan BCA Syariah berpengaruh cukup signifikan pada variabel FDR/LDR, sedangkan pada variabel (NPF/NPL), GCG dan CAR tidak berpengaruh secara signifikan. 


\section{KESIMPULAN}

Berdasarkan peringkat komposit tingkat kesehatan bank, semua komponen yang menunjukkan tingkat kesehatan bank yaitu CAR, NPF, BOPO, NOM, LDR dan ROA PT.Bank BCA,Tbk berada pada Peringkat Komposit-1 (PK-1). Untuk PT. Bank BCA Syariah, hanya komponen CAR, NPF, dan BOPO pada Peringkat Komposit-1 (PK-1), sementara NOM pada Peringkat Komposit-4 (PK-4), FDR pada Peringkat Komposit-3 (PK-3) dan ROA pada Peringkat Komposit-3 (PK-3). Dapat dikatakan PT. Bank BCA, Tbk memiliki tingkat kesehatan yang berbeda (lebih baik) dibandingkan PT. Bank BCA Syariah. Secara parsial juga terdapat perbedaan kedua bank tersebut terkait variabel tingkat kesehatan bank yang berpengaruh terhadap profitabilitasnya, yaitu BOPO pada PT.Bank BCA,Tbk yang berpengaruh signifikan negatif dan NOM pada PT. Bank BCA Syariah yang berpengaruh signifikan positif. Perbedaan juga terjadi dalam terkait besarnya pengaruh variabel kesehatan bank terhadap profitabilitas, yaitu untuk PT. Bank BCA, Tbk adalah ,782 atau 78.2 \%, sementara untuk PT. Bank BCA Syariah adalah 0,907 atau $90.7 \%$. Namun, secara simultan, tidak terdapat perbedaan pada kedua bank, dimana seluruh varibel tingkat kesehatan bank berpengaruh terhadap profitabilitas.

\section{DAFTAR PUSTAKA}

(OJK), O. J. K. R. (n.d.). Laporan Keuangan Perbankan. Jakarta. Retrieved from https://www.ojk.go.id/id/kanal/perbankan/data-dan-statistik/laporan-keuanganperbankan/default.aspx

(OJK), O. J. K. R. (2021). Peraturan OJK-Tingkat Kesehatan Bank Umum dan Bank Syariah. Jakarta: Otoritas Jasa Keuangan RI (OJK). Retrieved from https://www.ojk.go.id/id/Default.aspx

Andriyani Ima, R. P., \& Mayasari, dan D. S. A. (2018). Soundness Rating of Commercial Banks Before and After Implementation of RGEC Method in Indonesia. Jurnal Keuangan Dan Perbankan, 22(1), 162-169.

Danar Maharudin, A. (2019). Efisiensi Perbankan Syariah Di Indonesia. Jurnal Ekonomi Dan Kebijakan, 2(7), 1-11. Retrieved from https://doi.org/10.15294/jejak.v7i2.3895\%0A

Diana Putri1, R. V. U. D. A. E. S. W. (2021). Perbandingan Tingkat Kesehatan Kinerja BCA Konvensional Dan BCA Syariah Dengan Metode RGEC. . . Ekombis Review: Jurnal Ilmiah Ekonomi Dan Bisnis, https://doi.org/https://doi.org/10.37676/ekombis.v9i2.1450

Dinar Riftiasari 1), S. 2). (2020). ANALISIS KINERJA KEUANGAN BANK BCA KONVESIONAL DAN BANK BCA SYARIAH AKIBAT DAMPAK PANDEMI COVID-19. Jurnal Manajemen Bisnis (JMB), 33(2). Retrieved from http://ejournal.stieibbi.ac.id/index.php/jmb

Hendrawan, R., Akbar, L. M., \& Aminah, W. (2020). Can the Implementation of Sharia Banks ' Roadmap Increase Their Performance? ( Evidence from Indonesia 2012-2017 ), 
12(2), 179-190.

Indonesia, B. (2012). Kodifikasi Peraturan Bank Indonesia Kelembagaan Penilaian Tingkat Kesehatan Bank. Jakarta: Riset dan Edukasi Bank Sentral. Retrieved from https://docplayer.info/32766810-Kodifikasi-peraturan-bank-indonesia-kelembagaanpenilaian-tingkat-kesehatan-bank.html

Kasmir. (2014). Bank dan Lembaga Keuangan Lainnya (Revisi). Jakarta: Rajawali Press.

Komisioner, D., \& Jasa, O. (2016). Otoritas jasa keuangan republik indonesia.

Manik, S. (2017). Pengaruh Kerja Terhadap Disiplin Kerja Pegawai Kantor Camat Pendalian Iv Koto Kabupaten Rokan Hulu. Jurnal Internasional Ilmu Sosial dan Bisnis. Jurnal Internasional Ilmu Sosial Dan Bisnis, 4(1), 157. Retrieved from https://doi.org/10.23887/ijssb.v1i4.12526

Mukhlis, I. (2012). Kinerja keuangan bank dan stabilitas makroekonomi terhadap profitabilitas bank syariah di indonesia, 16(2), 275-285.

Pambudi, S., Darmawan, A. (n.d.). Analisis Kinerja Bank Umum Syariah dengan Metode Risiko Berdasarkan Peringkat Bank (RBBR) untuk Mengetahui Tingkat Kesehatan Bank. Jurnal Administrasi dan Bisnis, 56 (1), 127-136. Jurnal Administrasi Dan Bisnis, 56(2), $127-136$.

Rahadjeng, E. R. (2017). Pengaruh Perputaran Piutang dan Pengumpulan Piutang Terhadap Likuiditas Perusahaan Otomotif dan Komponen yang Tercatat di Bursa Efek Indonesia." Seminar Nasional Dan Gelar Produk. In Seminar Nasional Dan Gelar Produk.

Rahman, T. A. S. (2020). Banking Performance: An Empirical Study in Indonesia. Muqtasid -Syariah Accounting Department, IAIN Salatiga, 10(2), 139-154. https://doi.org/DOI:http://dx.doi.org/10.18326/muqtasid.v10i2.139-154

Rasyid, H. Al, \& Sazly, S. (2021). Pengaruh Penerapan Manajemen Risiko Terhadap Kinerja Keuangan Triwulan 2016 - 2020 Pada Bank Pembangunan Daerah Jawa Timur, 5, 283-294.

Saputri Ramadhanti. (2021). ANALISIS PERBANDINGAN KINERJA KEUANGAN ANTARA BCA DENGAN BCA SYARIAH BERDASARKAN RASIO KEUANGAN PADA PERIODE 2013 - 2019. INSTITUT AGAMA ISLAM NEGERI BENGKULU.

Suhartono, D. (. (n.d.). Analisis Tingkat Kesehatan Bank dengan Menggunakan Metode Risk Based Bank Rating (Studi pada Bank Milik Pemerintah Pusat yang Terdaftar di Bursa Efek Indonesia Tahun 2012-2015). (Studi Pada Bank Milik Pemerintah Pusat Yang Terdaftar Di Bursa Efek Indonesia Tahun 2012-2015). Jurnal Administrasi Bisnis, 46 (1), 131-139, 46(1), 131-139.

Umiyati, Laila Maisyarah, M. K. (2020). Islamic Corporate Governance And Sharia 
Compliance On Financial Performance Sharia Bank In Indonesia. Al-Iqtishad: Jurnal Ilmu Ekonomi Syariah, 12(1). Retrieved from http://journal.uinjkt.ac.id/index.php/iqtishad/article/view/15053

Zainuddin. (2016). Pengaruh CAR, BOPO, dan NPF Terhadap Profitabilitas (ROA) pada PT. Bank Rakyat Indonesia Syariah (BRIS) Syariah). Diperoleh dari website IAIN Padang Sidempuan: http://etd.iain-padangsidimpuan.ac.id/687/ Zubaidi, Z., Studi, P., Dan, K., Islam, P., Islam, U. Website IAIN Padang. Retrieved from http://etd.iainpadangsidimpuan.ac.id/687/ 